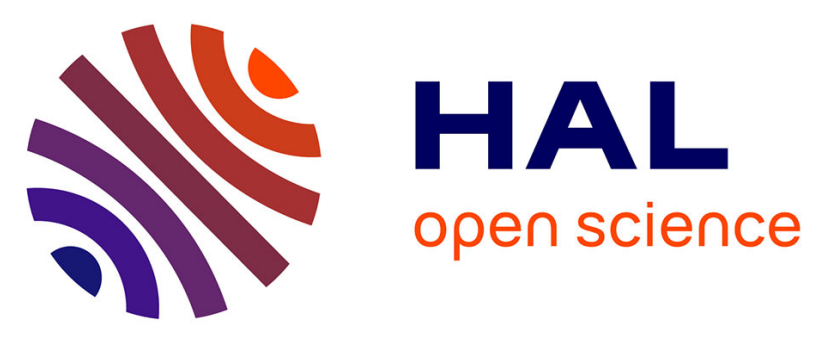

\title{
Effects of maternal au-np exposure by inhalation on feto-placental development and placental function, in a rabbit model
}

Delphine Rousseau-Ralliard, Valérie Fessard, John Boere, Paul Fokkens, Michèle Dahirel, Christophe Richard, Luc Jouneau, Catherine Archilla, Laurent Gaté, Sylvie Huet, et al.

\section{To cite this version:}

Delphine Rousseau-Ralliard, Valérie Fessard, John Boere, Paul Fokkens, Michèle Dahirel, et al.. Effects of maternal au-np exposure by inhalation on feto-placental development and placental function, in a rabbit model. IFPA 2019, Sep 2019, Buenos Aires, Argentina. , 135 p., 2019, IFPA 2019- VIII SLIMP Full Program Book. hal-02733979

\section{HAL Id: hal-02733979 \\ https://hal.inrae.fr/hal-02733979}

Submitted on 2 Jun 2020

HAL is a multi-disciplinary open access archive for the deposit and dissemination of scientific research documents, whether they are published or not. The documents may come from teaching and research institutions in France or abroad, or from public or private research centers.
L'archive ouverte pluridisciplinaire HAL, est destinée au dépôt et à la diffusion de documents scientifiques de niveau recherche, publiés ou non, émanant des établissements d'enseignement et de recherche français ou étrangers, des laboratoires publics ou privés. 
EFFECTS OF MATERNAL AU-NP EXPOSURE BY INHALATION ON FETOPLACENTAL DEVELOPMENT AND PLACENTAL FUNCTION, IN A RABBIT MODEL

Rousseau-Ralliard Delphine ${ }^{1,2}$, Fessard Valérie ${ }^{3}$, Boere John ${ }^{4}$, Fokkens Paul ${ }^{4}$, Dahirel Michèle $^{1,2}$, Richard Christophe ${ }^{1,2}$, Jouneau Luc ${ }^{1}$, Archilla Catherine ${ }^{1}$, Gaté Laurent ${ }^{5}$, Huet Sylvie ${ }^{3}$, Meslier Lisa ${ }^{3}$, Fournier Natalie ${ }^{6}$, Aubrière Marie-Christine ${ }^{1,2}$, Gelin Valérie $^{1,2}$, Marie-Sylvie Lallemand ${ }^{1,2}$, Aïoun Josiane ${ }^{1,2}$, Duranthon Véronique ${ }^{1}$, Chavatte-Palmer Pascale ${ }^{1,2}$, Laloë Denis ${ }^{7}$, Jaffrézic Florence ${ }^{7}$, Flemming Cassee ${ }^{4}$, Couturier-Tarrade Anne ${ }^{1,2}$

1- UMR BDR, INRA, ENVA, Université Paris Saclay, Jouy en Josas, France

2- PremUp Foundation, Paris, France

3- ANSES, Laboratoire de Fougères, BioAgroPolis, Fougères, France

4- National Institute for Public Health and the Environment (RIVM), Bilthoven, The Netherlands

5- INRS, Département Toxicologie et Biométrologie, Vandoeuvre, France

6- Hôpital Européen Georges Pompidou (AP-HP), Laboratoire de Biochimie, UF CardioVasculaire, Paris, France.

7- UMR GABI, INRA, Université Paris Saclay, Jouy en Josas, France

Gold nanoparticles (Au-NP) are contained in consumer and medical products leading to an potential of workers being exposed to Au-NP among them pregnant women, but effects of Au-NP on offspring is still unclear. The aim was to evaluate the effects of maternal sub-chronic Au-NP inhalation throughout the gestation on the feto-placental development and placental function in a rabbit model.

11 pregnant females (Au-NP) inhaled uncoated Au-NP (11.5nm) at $132 \pm 38 \mu \mathrm{g} / \mathrm{m}^{3}$ for 5 days/week, from 1-27dpc of gestation. 11 controls were exposed to clean air in the same conditions. Gestation was monitored by ultrasound. At $28 \mathrm{dpc}$, maternal bronchoalveolar fluid, hematology and biochemistry, maternal and fetal biometry were analyzed using a linear models. DNA lesions were evaluated by alkaline comet assay and Au quantified by neutron activation in various maternal and male fetal tissues. Placental gene expression was explored using a customized microarray.

Fetal growth was not affected, although umbilical Doppler resistance was increased at $27 \mathrm{dpc}$ in Au-NP. At 28dpc, maternal lymphocytes numbers were increased in bronchoalveolar fluid from Au-NP. Maternal blood mean corpuscular volume was significantly decreased in Au-NP, whereas maternal biometry and biochemistry, fetal biometry remained unchanged. At $28 \mathrm{dpc}$, DNA lesions were detected in maternal bone marrow and in male, but not female, fetal kidneys. Au-NP were strongly detected in maternal lungs, liver and plasma and in the placenta, heart, lungs and kidneys of male fetuses, but not in brain. 3 genes were differentially expressed between groups. Gene Set Enrichment Analysis revealed opposite gene set enrichment profiles in Au-NP males and females compared to $\mathrm{C}$.

Maternal and fetal phenotypes were weakly affected by in utero exposure to Au-NP through maternal inhalation but DNA lesions were observed. Moreover, Au-NP were able to reach placental and fetal tissues and to affect placental gene expression in a sex-specific manner.

\section{Guidelines:}

- Maximum word count is 300 words.

- The abstract should be structured in the following sections: Objective, Methods, Results and Conclusions. 
- The presenting author must be registered before 15th May 2019 for further publication of the abstract in Placenta Journal.

- Abstracts should not be submitted if the content has been accepted for publication AND will be available (on line or in paper) prior to the IFPA meeting in September. 